\title{
CYANOBACTERIA AS ALTERNATIVE BIOLOGICAL CONDITIONERS FOR BIOREMEDIATION OF BARREN SOIL
}

\author{
Ibraheem B. M. Ibraheem \\ Botany Department, Faculty of Science, Beni-Suef University, Beni-Suef, Egypt
}

\begin{abstract}
In this study, synthetic and biological soil conditioners were used to screen their abilities to improvise the barren soil characters. These soil conditioners based on treatment of barren soil samples with urea and / or compost as synthetic soil conditioner or by inoculating the soil samples with Spirulina meneghiniana Zanrd. ex Gomon and / or Anabaena oryzae Fritsch as a biological soil conditioner. The data revealed that, the biological conditioner in a mixture $\left(22.5 \mathrm{~kg} \mathrm{ha}^{-1}\right.$ Anabaena and $22.5 \mathrm{~kg} \mathrm{ha}^{-1}$ Spirulina supplied with $7.5 \mathrm{~kg} \mathrm{ha}^{-1}$ urea and $7.5 \mathrm{~kg} \mathrm{ha}^{-1}$ compost) was the most effective one. Also, the soil samples inoculated with this mixture exhibited positive activity of improving soil characters. Moreover, highly significant positive responses of the development features were appeared on lettuce plants transplanted in such soil samples.
\end{abstract}

Keywords: Biological conditioners, Barren soil, Cyanobacteria.

\section{Introduction}

In the last decades, considerable emphasis has been placed on the use of a wide array of chemicals purporting to favorably influence soil properties. Some materials are produced directly for such purposes, while others are by-products of industrial processes.

Soil conditioners have potential importance in the arid and semi-arid regions of the world where there is a developing awareness of the implications of soil erosion and inefficient water use. In recent years, much considerations were sent towards the possibility of using the biological conditioners to provide some economic assistance to the small and marginal farmers and to introduce a judicious combination of linear and cyclic fertilization of soils, where the use of biological conditioners reduces the resultant pollution to soil and plants together in addition to their ability to improve both soil and plant properties (Banerjee \& Kumar, 1992; Silke et. al,. 2007).

Cyanobacteria are able to survive in extreme environments because of unique adaptations such as their capability of fixing $\mathrm{N}_{2}$ (Paerl et. al.,1995; Bergman et al., 1997) and their resistance to desiccation (Potts, 1996 \& 1999). Because of the ability to fix atmospheric nitrogen, cyanobacterial mats have been used as biofertilizer in modern agriculture (Mandal et. al., 1999; Ladha \& Reddy, 2003). Moreover, cyanobacterial mats contribute to the overall ecosystem primary production and play a key role in nutrient cycle (Goldsborough \& Robinson, 1996; McCormick \& O'Dell 1996; Scott et. al., 2005; Rodrigo \& Eberto, 2007 ). 
Many trails have been conducted to increase plant yield by cyanobacterial inoculation (algalization) (Roger \& Kulasoority, 1980). Algalization has been reported to have a beneficial effect on grain yield (Dong et. al., 1995; El-Ayouty, 1998). However, other reports indicated failure of algalization under widely different agro-climatic conditions (Roger \& Watanabe, 1981).

The growth of Cyanobacteria creates the conditions for colonization by higher plants since they are sources for biological change and accumulation of humus and nitrogen. They also indicate soil quality and help to protect the soil crust from erosion. In this respect Kaushik \& Murti, (1981) studied the effect of Cyanobacteria on physico-chemical properties of alkali soils. They found that application of Cyanobacteria resulted in significant improvement in the aggregation status of soil and brought down appreciably the $\mathrm{pH}$, electric conductivity and exchangeable sodium, furthermore they increased considerably the hydraulic conductivity of soil.

Cyanobacterial fertilizers are a promising alternative to avoid soil pollution caused by agrochemical. They may recover the nutrient content and structure lost after harvesting as they bring to soil combined exoploysaccharide, that aggregate soil particles which helps to reduce erosion and improve soil structure (Oesterreicher, 1990), and bioactive substances that enhance seedlings growth (De Caire et. al., 1997; De Mule et. al., 1999). The agricultural importance of Cyanobacteria lies in their capacity to fix and metabolize the molecular nitrogen thus, liberating a part of the fixed nitrogen and possibly growth regulators as extrametabolites (Omar, 2000). Also, some investigators (Roger \& Kulasooriya, 1980; Goyal, 1989) reported the solubilizing of the insoluble phosphate, addition of organic matter and improving the physical and chemical nature of soil.

Singh et. al., (1988) found that application of higher levels of nitrogen fertilizers urea 60-90 kg N/ ha inhibits the growth of Azolla and Cyanobacteria. However, Cyanobacteria inoculation had a significant effect on the grain and straw yields during the dry season with adding $30 \mathrm{~kg} \mathrm{~N} / \mathrm{ha}$. Abd-All et. al., (1994) found that the inoculating of soil with living Cyanobacteria alone or in supplement with $\mathrm{K}, \mathrm{P}$ and $\mathrm{S}$ significantly increased dry weight, total nitrogen and pigment content of wheat plant. Blunden et. al., (1997) found that the application of an aqueous alkaline extracts of Ascophyllum nodosum to the soil resulted in higher concentration of chlorophyll in leaves of treated plants, also foliar spraying of extracts had similar effects on leaf chlorophyll. Finally, Hassan (2007) found that the presoaking of tomato seeds in Chroococcus minetus extract enhanced the germination percentage, shoot and root length and also increase the chlorophyll contents although they seeded in infested soils with pathogenic Pythium sp. The objective of the present study was to examine the ability of some cyanobacterial strains to improve soil characters and their efficiency on lettuce development. 


\section{Materials and Methods}

Soil samples. Soil samples were obtained from agricultural soil described as barren soil from Beni-Suef Governorate. The soil samples were analyzed to determine the physico-chemical properties before treatment.

Cynobcterial isolates: Local Cyanobacterial species, Anabaena oryzae Fritsch and Spirulina meneghiniana Zanrd. ex Gomont were isolated from agricultural soils at Beni-Suif city and identified according to Desikachary (1959).

Soil based inoculums. Anabaena oryzae Fritsch and Spirulina meneghiniana Zanrd. ex Gomont were propagated in the laboratory on Watanabe medium modified by El-Nawawy et. al., (1958) under continuous illumination (3000 Lux) and $29 \pm 1{ }^{\circ} \mathrm{C}$. After three weeks, the considerable cyanobacterial growth was collected by filtration and used to produce the soil based inoculums (SBI). The SBI was then prepared in a greenhouse according to Venkataraman's method (1981) using shallow galvanized iron trays $(50 \mathrm{~cm}$ x $50 \mathrm{~cm} \times 15 \mathrm{~cm}$ ) containing $10 \mathrm{~kg}$ clay, $5-15 \mathrm{~cm}$ tap water above the soil , $200 \mathrm{~g}$ super-phosphate and covered with gauze to prevent the insect attack. After the soil has settled, $50 \mathrm{ml}$ of fresh grown cyanobacterial strains were sprinkled on the surface of the standing water. Two weeks later, the growth of the Cyanobacteria covered the surface of water forming thick mat. Water was then allowed to evaporate completely in the sun. The remained dry Cyanobacteria formed mat will crack into flasks which represent the soil based inoculums.

Pot experiment. Plastic pots of $15 \mathrm{~cm}$ diameter were used in this experiment. About $1 \mathrm{~kg}$ of barren soil was put in each pot.

Treatment of barren soil. The effect of chemical, organic or biological fertilizers on soil features, growth and productivity of lettuce were studied in plastic pots. The chemical fertilizer (urea), organic fertilizer (compost) or Cyanobacteria fertilizer (SBI) were added to the pots in a total of $60 \mathrm{~kg} \mathrm{~N} \mathrm{ha}^{-1}$ (as recommended by the Egyptian ministry of Agricultural) according to the following sequences with three replicates for each treatment:

$\mathrm{C}=\mathrm{Control}, \mathrm{T} 1=100 \%$ Spirulina, $\mathrm{T} 2=100 \%$ urea, $\mathrm{T} 3=100 \%$ compost, $\mathrm{T} 4=50 \%$ Spirulina $+50 \%$ urea, T5 $=50 \%$ Spirulina $+50 \%$ compost, $\mathrm{T} 6=50 \%$ urea +50 $\%$ compost, $\mathrm{T} 7=50 \%$ Spirulina $+25 \%$ urea $+25 \%$ compost, $\mathrm{T} 8=50 \%$ Spirulina $+50 \%$ Anabaena, $\mathrm{T} 9=37.5 \%$ Spirulina $+37.5 \%$ Anabaena $+25 \%$ urea, $\mathrm{T} 10=37.5 \%$ Spirulina $+37.5 \%$ Anabaena $+25 \%$ compost, $\mathrm{T} 11=37.5 \%$ Spirulina $+37.5 \%$ Anabaena $+12.5 \%$ urea $+12.5 \%$ compost, $\mathrm{T} 12=100 \%$ Anabaena, T13 $=50 \%$ Anabaena $+50 \%$ urea, T14 $=50 \%$ Anabaena $+50 \%$ compost, $\mathrm{T} 15=50 \%$ Anabaena $+25 \%$ urea $+25 \%$ compost. The treated pots were waited by water for three weeks before transplanting of lettuce to allowed the treatment to be effective. 
Soil analysis. Soil samples (three weeks after treatment) in replicates were taken from treated pots for physico-chemical analysis to determine the effect of different treatments on soil properties before transplanting of lettuce. Maximum water holding capacity, gravitational and capillary water were determined according to the Standard Methods (1998). Total nitrogen was determined by Kjeldahl method as described by Tan (1996). Organic carbon (Piper, 1950), exopolysaccharides (Lowe, 1993), total carbonate (Hesse, 1994), and $\mathrm{pH}$ (Jackson, 1976) were also measured. Available nitrogen was determined according to Markus et. al., (1982), available phosphorus was extracted as described by Olsen et. al,. (1954) and determined calorimetrically according to Jackson (1976). Available potassium was extracted by ammonium acetate solution as described by Jackson (1976), and then measured by Flame photometer. Acetylene-reducing activity (ARA) was assayed by acetylene reduction technique according to Hardy et al., (1973).

Transplanting of lettuce. Five lettuce seedlings 15 days old were transplanted per pot. The pots were irrigated daily. The experiment was conducted for 25 days

Plant analysis. The plant was harvested for determination of shoot length, chlorophyll contents (Vernon and Seely, 1966), total soluble carbohydrates according to Umbriet et. al., (1969) and protein contents according to Lowery et. al.,(1951).

Statistical analysis. Analysis of variance (one-way ANOVA) was employed to determine if treatments were significantly different for each other (Zar, 1984). Results were seemed significantly different at the levels of 5 and $1 \%$. All experiment was repeated of three replicates.

\section{Results}

The changes in water holding capacity of soil in respect to the different treatments as show in Figure (1) revealed that no significant changes with treatments T2, T3 and T6 as compared with control. But the other applicable treatments were high significant increasing in water holding capacity.

Data illustrated in Figure (2), showed that, treatments T2, T3, T6 and T13 confirmed similar contents of soil capillary water as in control. Meanwhile, all other treatments revealed significant difference in soil capillary water especially with T5 and T7 which exhibit high significant difference as compared with control.

Table (1) showed contents of the gravitational water of the tested soil samples. The data revealed that the maximum value of gravitational water $(86.33$ $\mathrm{ml} / 100 \mathrm{ml}$ water passing through $20 \mathrm{~g}$ soil) was reported in soils with T15 which revealed a significant difference as compared with control and other treatments. 


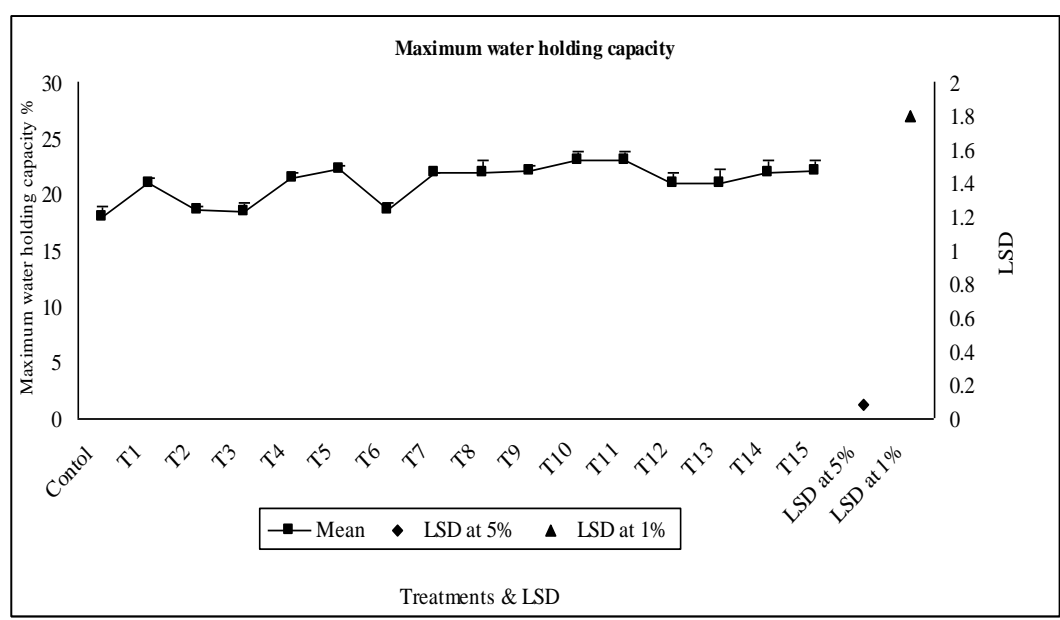

Figure (1): Percentage maximum water holding capacity of soil after treatment by Cyanobacteria and other treatments

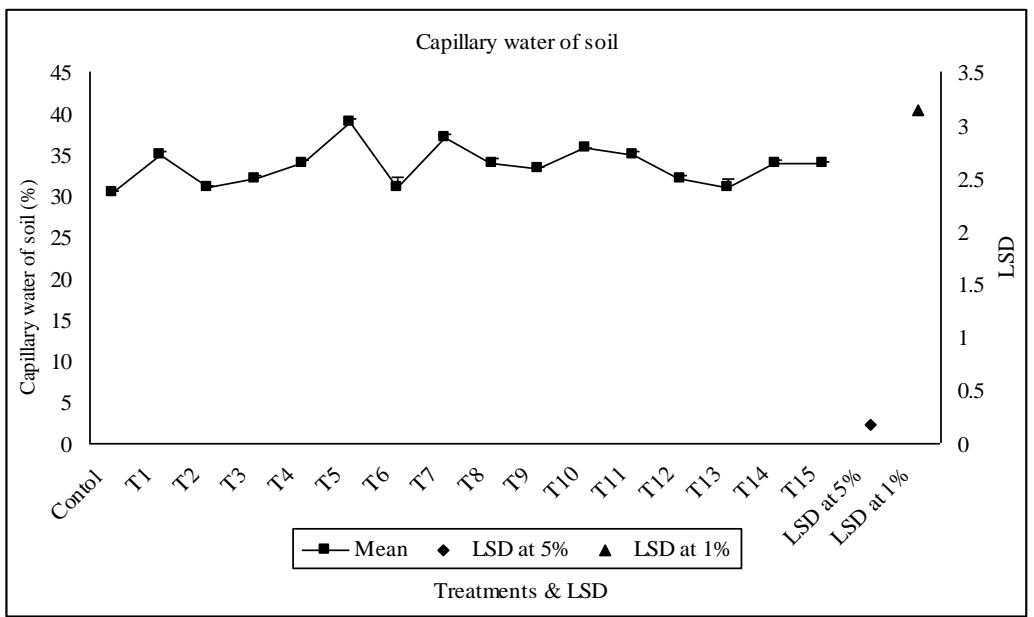

Figure (2): Capillary water percentage of soil after treatment by Cyanobacteria and other treatments

Results illustrated in Table 1 confirmed a significant increase in the $\mathrm{pH}$ values of the soil treated with chemical and/or organic fertilizers as compared with control. While it high significantly decreasing in $\mathrm{pH}$ value of soil inoculated by cyanobacterial species.

The changes in soil total nitrogen according to the 15 treatments as illustrated in Fig. 3 showed marked differences among experimental soils. All treatments exhibited high significant increasing in soil total nitrogen compared with control. In this respect, T4, T7 and T11 showed the highest value of soil total 
nitrogen $(116,113$ and $117 \mathrm{mg} / \mathrm{kg}$ soil, respectively) on account to the other treatments.

Table (1): Changes in gravitational water and $\mathrm{pH}$ value of studied soil after treatment by Cyanobacteria and other treatments. Data are the means of triplicate tests \pm SD.

\begin{tabular}{|c|c|c|}
\hline Treatments & $\begin{array}{c}\text { Gravitational } \\
\text { water } \\
\text { Mean } \pm \text { SD } \\
\end{array}$ & $\begin{array}{c}\text { pH value } \\
\text { Mean } \pm \text { SD }\end{array}$ \\
\hline Control & $85.9 \pm 0.1$ & $8.2 \pm 0.08$ \\
\hline T1(100\% Spirulina) & $86.0 \pm 0.06$ & $7.2 \pm 0.1$ \\
\hline T2 (100\% chemical fertilizer) & $85.7 \pm 0.15$ & $8.55 \pm 0.029$ \\
\hline T3 (100\% organic fertilizer) & $85.7 \pm 0.1$ & $8.0 \pm 0.1$ \\
\hline T4 (50 \% Spirulina + $50 \%$ chemical fertilizer) & $86.0 \pm 0.16$ & $7.5 \pm 0.15$ \\
\hline T5 (50\% Spirulina $+50 \%$ organic fertilizer) & $85.8 \pm 0.15$ & $7.9 \pm 0.04$ \\
\hline T6 $(50 \%$ chemical fertilizer $+50 \%$ organic fertilizer $)$ & $85.8 \pm 0.1$ & $8.2 \pm 0.104$ \\
\hline T7 (50 \% Spirulina $+25 \%$ chem. fer. $+25 \%$ org. fer.) & $85.9 \pm 0.15$ & $7.6 \pm 0.1$ \\
\hline T8 (50 \% Spirulina + $50 \%$ Anabaena $)$ & $85.7 \pm 0.17$ & $7.8 \pm 0.052$ \\
\hline T9 (32.5\% Spirulina + $32.5 \%$ Anabaena $+25 \%$ chem. fer.) & $85.7 \pm 0.1$ & $7.2 \pm \mathbf{0 . 0 5 7}$ \\
\hline T10 (32.5 \% Spirulina + 32.5\% Anabaena $+25 \%$ org. fer.) & $85.9 \pm 0.09$ & $7.1 \pm 0.15$ \\
\hline T11 (32.5\% S. + 32.5\% A. + $12.5 \%$ chem. fer. $+12.5 \%$ org. fer.) & $86.0 \pm 0.12$ & $7.4 \pm 0.1$ \\
\hline T12 (100\% Anabaena) & $85.8 \pm 0.21$ & $7.1 \pm 0.1$ \\
\hline T13 (50\% Anabaena + $50 \%$ chemical fertilizer) & $85.6 \pm 0.1$ & $7.46 \pm 0.04$ \\
\hline T14 (50 \% Anabaena + $50 \%$ organic fertilizer) & $85.6 \pm 0.35$ & $7.45 \pm 0.089$ \\
\hline T15 (50 \% Anabaena $+25 \%$ chem. fer. $+25 \%)$ & $85.6 \pm 0.35$ & $7.53 \pm 0.072$ \\
\hline LSD at $5 \%$ & 0.27 & 0.12 \\
\hline LSD at $1 \%$ & 0.37 & 0.147 \\
\hline
\end{tabular}

S.= Spirulina $;$ A.= Anabaena $;$ chem. fer= chemical fertilizer; org. fer.= organic fertilizer

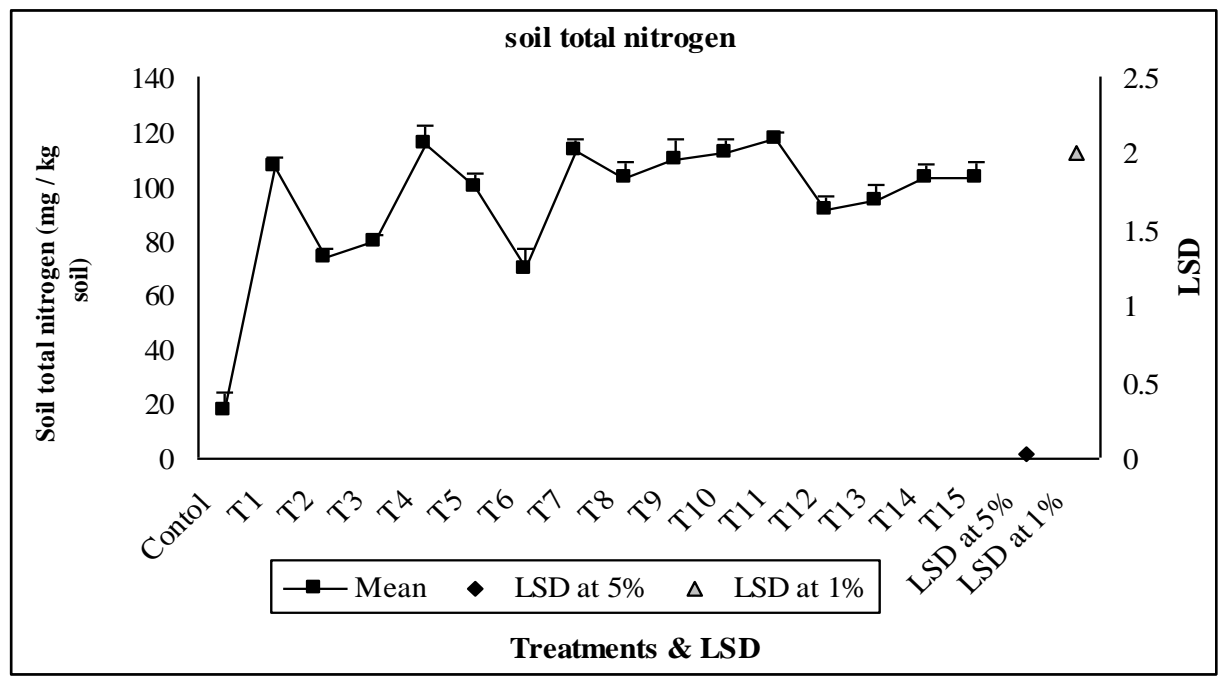

Figure (3): Changes in total nitrogen of soil after treatment by Cyanobacteria and other treatments 
Regarding all applicable treatments, the changes in the soil carbonates (Fig. 4) showed the maximum values $(8610,8403$ and $8014 \mathrm{mg} / \mathrm{kg}$ soil) of soil carbonates that recorded with treatments $\mathrm{T} 2, \mathrm{~T} 3$ and $\mathrm{T} 6$, respectively. While the other treatments, revealed a decreasing values fluctuated between significant or highly significant decreasing compared with control.

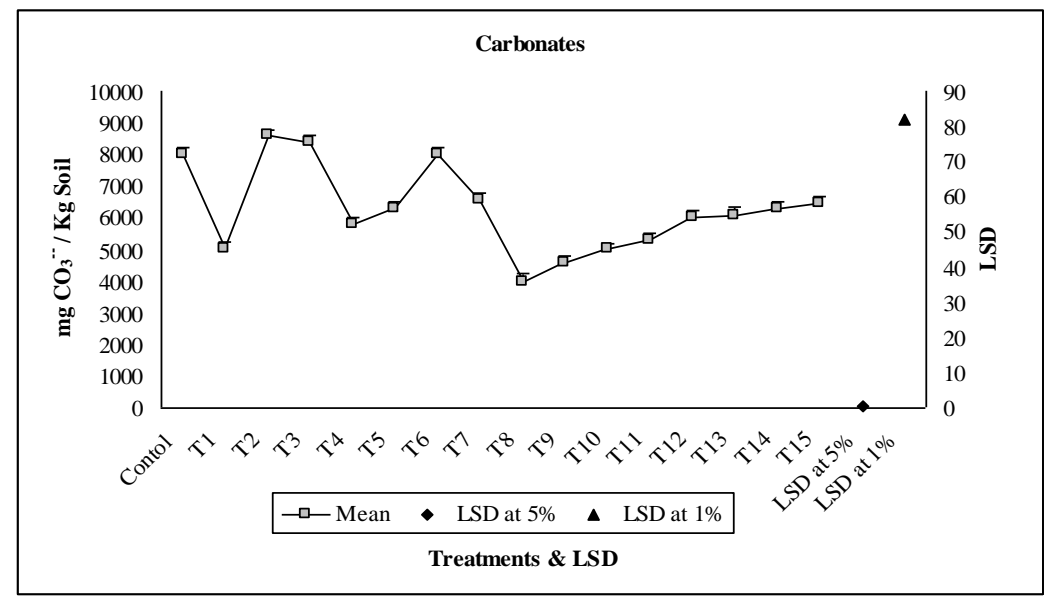

Figure (4): Changes in soil carbonates after treatment by Cyanobacteria and other treatments

Given data illustrated in Figure (5) showed that, high significantly increasing in soil organic carbon contents with all treatments compared to control. However, all soil samples inoculating with cyanbacterial species exhibited more increasing in soil organic carbon compared to the soil inoculating with urea (as chemical fertilizer) and/or organic fertilizer alone.

Data shown in Figure (6) confirmed clearly that all soils inoculated with studied Cyanobacteria had highly significant increasing in their contents of exopolysaccharides over control and/or chemical or organic fertilizers. Regarding all applicable treatments, data given in (Fig. 6) showed that, soil samples treated with T11 confirmed the highest value (370 mg / $\mathrm{kg}$ soil) followed by T10 (300 mg / $\mathrm{kg}$ soil) while the lowest values were recorded by control followed by T2, T3 and T6 (14, 20, 61 and $68 \mathrm{mg} / \mathrm{kg}$ soil, respectively).

The dynamics of acetylene-reducing activity (ARA) as shown in Figure (7) were similar in soils treated with urea (T2) or that treated by compost (T3) alone or in mixture (T6) with maximum ARA activity 55, 40 and $63 \mu \mathrm{mol} / \mathrm{h} /$ keg dry soil) for three treatments, respectively. In contrast, during the cyanobacterial treatments, ARA activity was high significantly increased with all investigated cyanobacterial species. In this respect, cyanobacterial mixture (T11 
and T9) recorded the highest ARA activity reached to 299 , and $290 \mu \mathrm{mol} / \mathrm{h} / \mathrm{keg}$ dry soil.

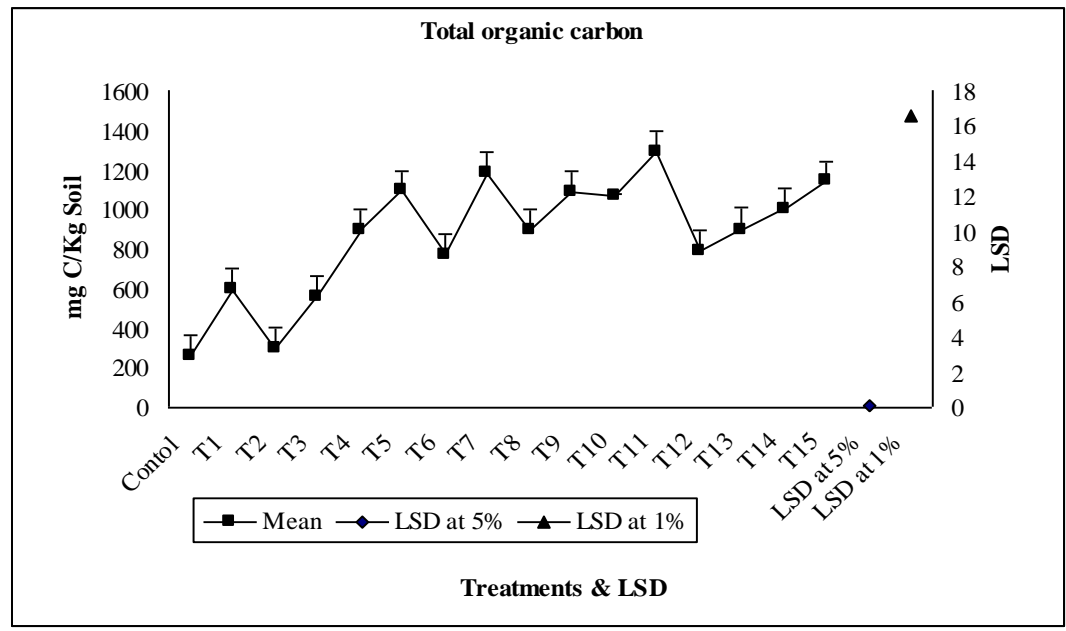

Figure (5): Changes in total organic carbon of soil after treatment by Cyanobacteria and other treatments

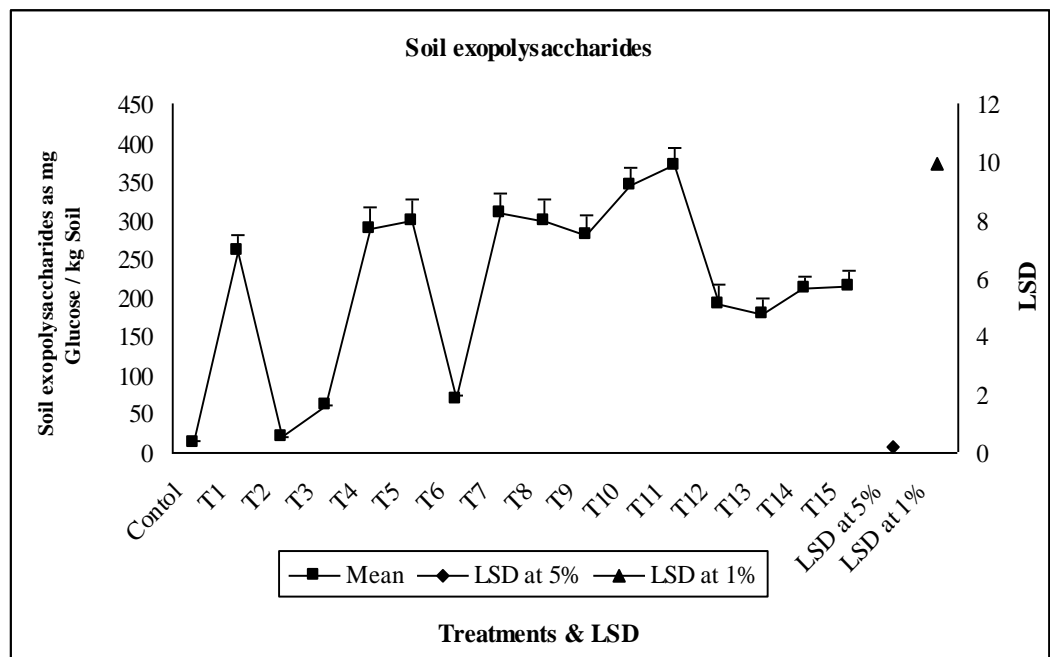

Figure (6): Soil exopolysaccharides after treatment by Cyanobacteria and other treatments

Data in (Fig. 8) revealed clearly the importance of Cyanobacteria to a certain extent, as the sole active soil reformer in addition to other assistant factors. Whereas the highest values of available N, P \& K in soil samples were recorded from soils inoculated with cyanobacterial mixture supplemented with urea and compost (T11) (350 mg kg ${ }^{-1}$ soil for $\mathrm{K}, 145 \mathrm{mg} \mathrm{kg}^{-1}$ soil for $\mathrm{N}$ and $60 \mathrm{mg} \mathrm{kg}^{-1}$ 
soil for P). In this respect the supplement of urea and compost was significantly initiates the activity of Anabaena in increasing the K contents of soil to $300 \mathrm{mg}$ $\mathrm{kg}^{-1}$ soil compared with the other treatments.

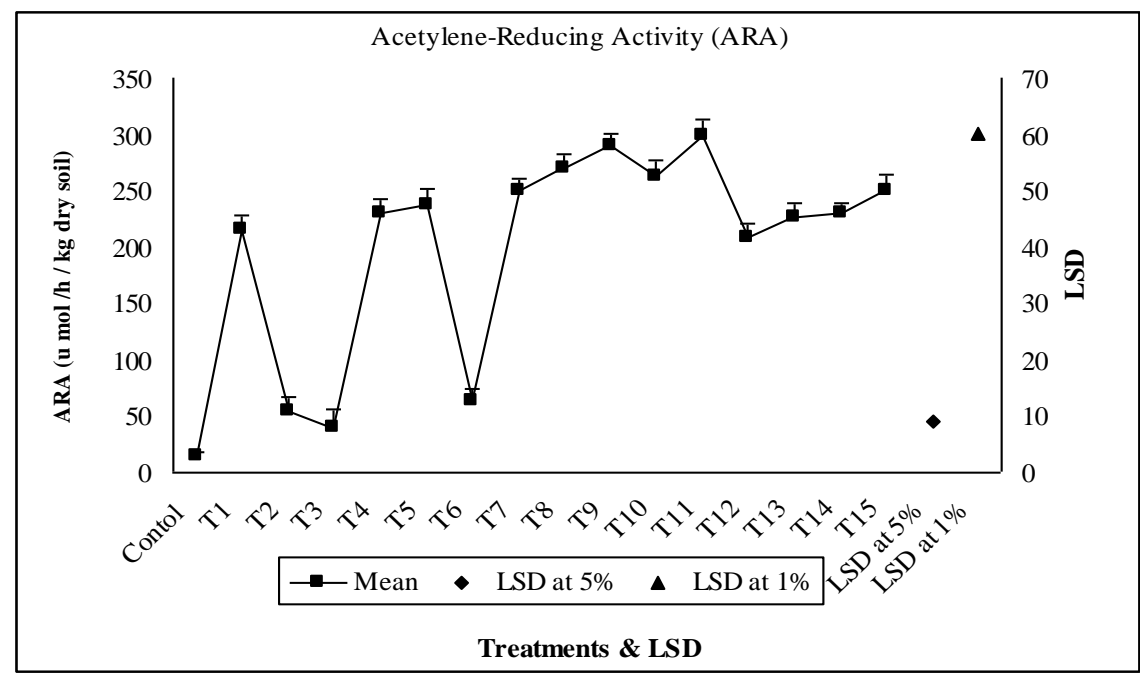

Figure (7): Average acetylene-reducing activity (ARA) in the soil after treatment with Cyanobacteria and other treatments

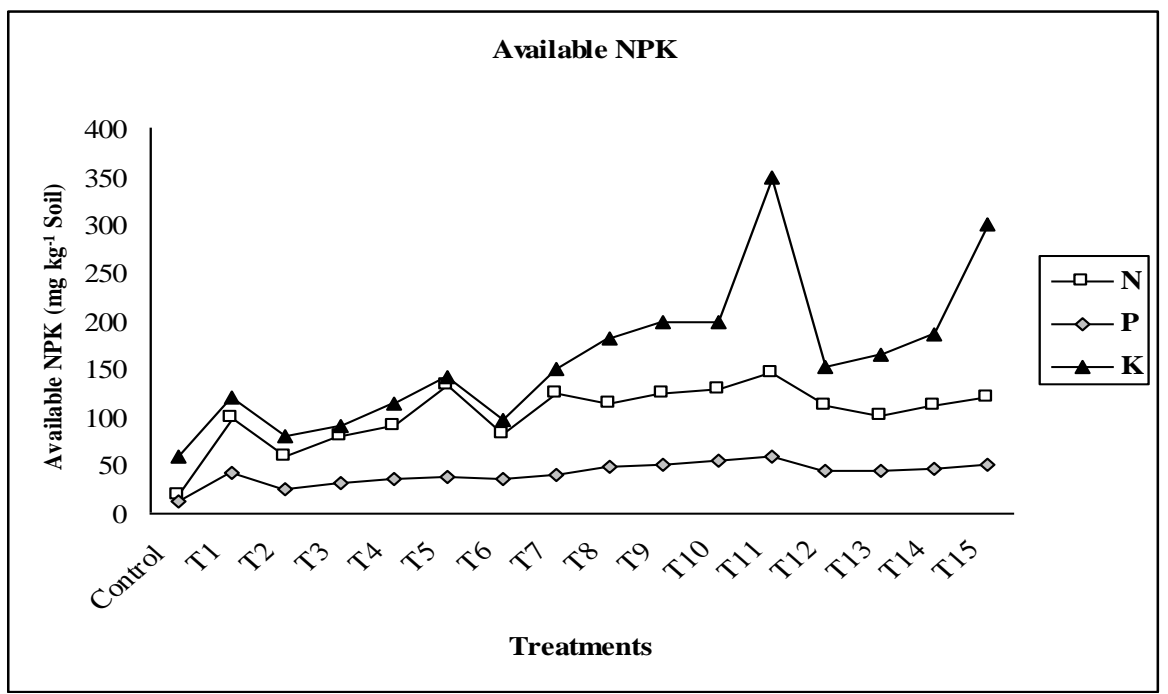

Figure (8): Available N, P \& K of soil after treatment with Cyanobacteria and other treatments 
Regarding the development percentage of the used lettuce plant in the experimental soils, it was found that there is no productivities appeared on the lettuce seedlings transplanted in the controlled soil, while the other transplanted in algalized soil samples were exhibited very high significant difference in the productivity and development percentages.

Results illustrated in Figure (9) confirmed that the addition of the cyanobacterial species to tested soil samples was significantly increased the shoot length of lettuce plant as compared with that treated by urea and / or compost. In this respect the treatment with $32.5 \%$ Anabaena and $32.5 \%$ Spirulina supplied with $12.5 \%$ urea and $12.5 \%$ compost (T11) was recorded the highest shoot length $(14.5 \mathrm{~cm})$ followed by the treatments; T10 and T9 $(14$ and $13.5 \mathrm{~cm}$, respectively).

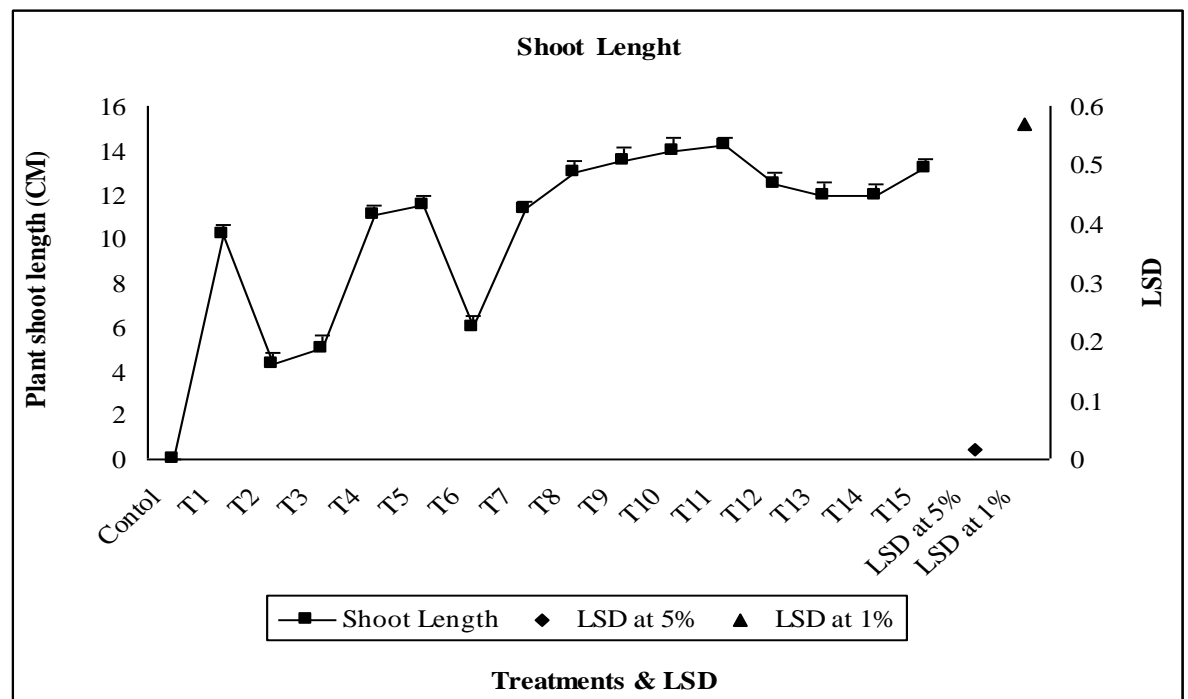

Figure (9): Shoot length of lettuce plant growing in soil treated with Cyanobacteria and other treatments

Regarding the chlorophyll contents of lettuce plant (Fig. 10), it was found that all applicable treatments exhibited high significant increasing in chl-a, chl-b and total chlorophyll. However, T11 recorded the highest significant content of chl-a (22.13 $\mu \mathrm{g} / \mathrm{g}$ fresh weight), chl-b $(25 \mu \mathrm{g} / \mathrm{g}$ fresh weight) and total chlorophyll (47.13 $\mu \mathrm{g} / \mathrm{g}$ fresh weight).

Statistical analysis among all treatments showed highly significant increasing in carbohydrate contents of lettuce plants that treated with all studied cyanobacterial species compared with that treated by chemical and / or organic fertilizers (Fig. 11). However, no considerable changes were appeared between all cyanobacterial treatments employed. 


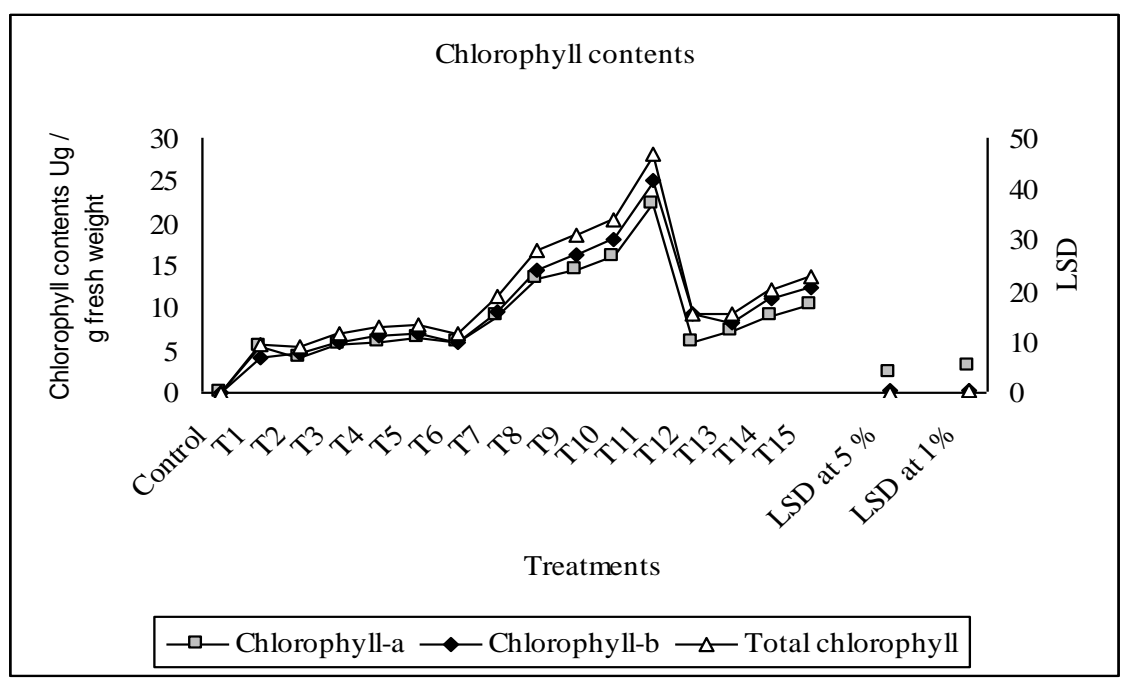

Figure (10): Chlorophyll- a, -b and total chlorophyll of lettuce plant growing in soil treated with Cyanobacteria and other treatments

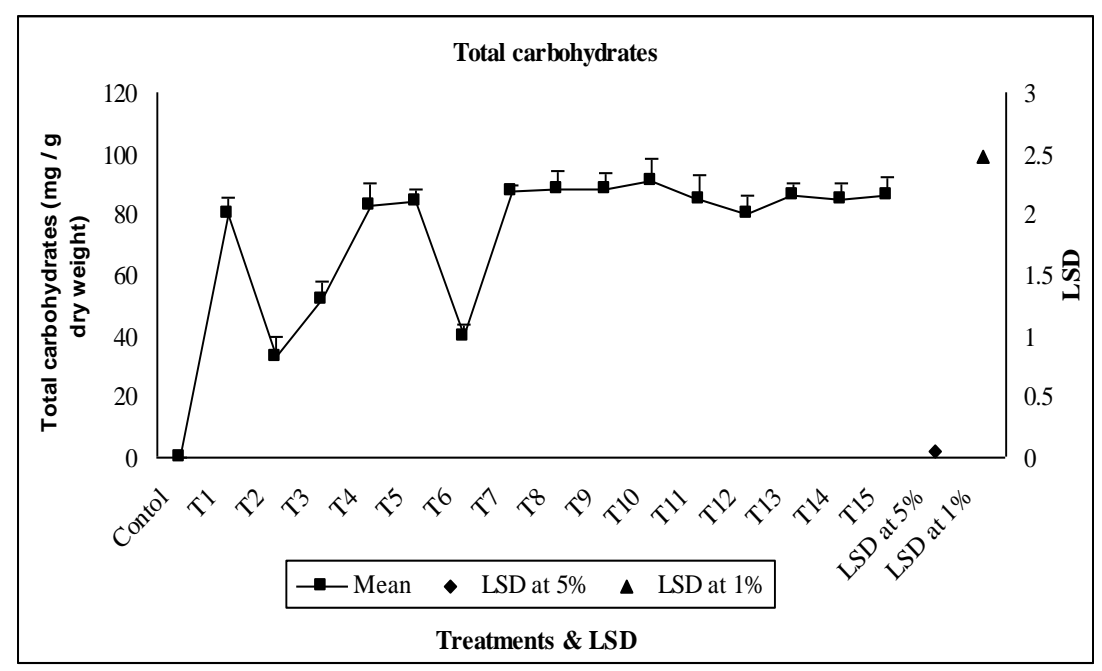

Figure (11): Total carbohydrates of lettuce plant growing in soil treated with Cyanobacteria and other treatments

Data illustrated in Figure (12) referred to the pattern of the total soluble proteins of the growing plants. Lettuce plants seeded in soils inoculating with all cyanobacterial treatments exhibited a very high significant increasing compared with seeded in soil treated with chemical and/or organic fertilizers. Whereas, the 
highest significant protein contents were recorded with treatments T11, T10 and T9 (13.12, 12.2 and $12 \mathrm{mg} / \mathrm{g}$ fresh plant, respectively).

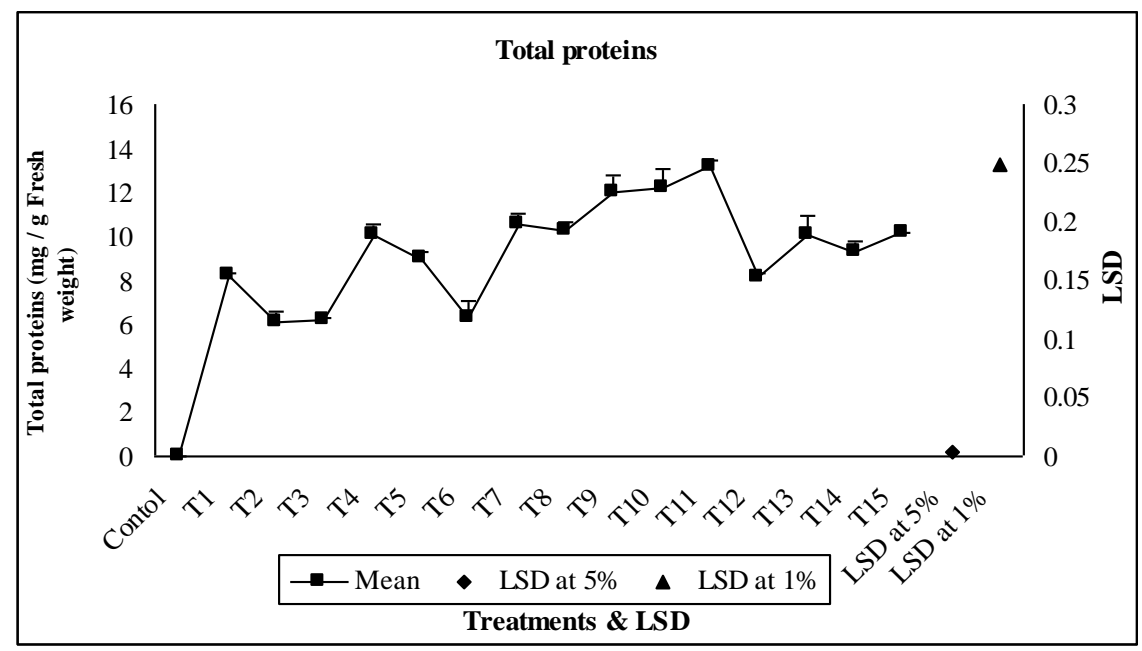

Figure (12): Total proteins of lettuce plant growing in soil treated with Cyanobacteria and other treatments

\section{Discussion}

Overview the present results indicated that soil properties under cyanobacterial inoculations differ significantly from those receiving no cyanobacterial treatments. Such results supported the opinion that Cyanobacteria incorporation to soil as a biofertilizer plays an important role in improving soil properties without any consideration to other different treatments employed. In this respect, the data showed significant increase in water holding capacity, capillary and gravitational water. These results were in a good agreement parallel with those reported by Shields \& Durrell (1964) and Metting \& Rayburn, (1983) who stated that cyanobacterial incorporation to soil stabilized the surface crust, improve infiltration and increased water retention and soil particles aggregation.

Regarding the changes in soil $\mathrm{pH}$ values, the data showed a significant decreasing in soil $\mathrm{pH}$ with cyanobacterial inoculation. While, all results concerning soils with urea or compost showed significant increasing in $\mathrm{pH}$ values in comparison with control. In the same manner, Singh (1961) and Kaushik \& Murti, (1981) reported the reduction in alkaline soil $\mathrm{pH}$ with inoculation by Cyanobacteria from 9.5 to 7.6. This is very important in the bioremediation process of alkaline soil.

The calculated data indicated that all treatments exhibited high significant increasing in soil total nitrogen compared with control especially in soil treated 
with Cyanobacteria. In this respect Allison \& Moris, (1930); Singh, (1961); Grant et. al., (1986) and Ghosh \& Saha, (1993) stated that Cyanobacteria may be the most important nitrogen fixing agent in many agricultural soils. Fletcher \& Martin, (1948) found that the nitrogen of semi-desert soil increased $400 \%$ when cyanobacterial growth of nitrogen fixers was extensive. In most cases, it is generally accepted that the incorporation of organic carbon via photosynthesis and of organic nitrogen via nitrogen fixation are the most important contributions that Cyanobacteria add to the fertility of soil (Metting, 1981).

Regarding the changes in the carbonate contents, results generally revealed a significant reduction in carbonate contents of experimental soils that inoculating with cyanobacterial species over control. These data were also evidenced by Singh (1961).

In the light of the above findings all applicable treatments were significantly increase soil organic carbon. However, the maximum results were obtained from soils with treatment T11, where a mixture of $37.5 \%$ Anabaena and $37.5 \%$ Spirulina supplied with $12.5 \%$ urea and $12.5 \%$ compost was adopted. These data agree with that of Ghazal (1980); De Caire et. al., (1997); El-Zeky et. al., (2005) who found that the inoculation with Cyanobacteria increased soil organic content.

Concerning the high contents of exopolysaccharides appeared in soil that treated with studied cyanobacterial species, it may attributed to the activity of Cyanobacteria which described as exopolysaccharides producing organisms and exploited in this filed (Metting et al., 1988). In this respect, Falshini et. al., (1997) found that inoculation of soil with Cyanobacteria increase the soil contents of exopolysaccharides resulted in protection of soil porosity by reducing damaging effects of water and also being of primary aggregation as a consequence of interaction between the secreted exopolysaccharides and the units of the fine soil fraction.

Acetylene-reducing activity (ARA) was higher in soil inoculated with different cyanobacterial strains than that treated with urea or compost. These results indicate the enhancement of nitrogenase activity. Present results agree with that found by Quesada et. al., (1997) who reported the activity by Cyanobacteria is an important source of nitrogen input in the nitrogen cycle in soil and could limit pollution problems by lowering the demand for chemical fertilizers.

Concerning the available N, P \& K of treated soil samples, the given data indicate that Cyanobacteria inoculation either alone or in combination with different investigated fertilizers led to significant increases in soil available NPK over the control. This is agreeing with that obtained by Singh et. al., (1988) who found that total nitrogen, available $\mathrm{P}$ of soil had been increased owing to the application of blue-green algae. 
Evaluation the response of lettuce plants to grow, develop and flourish in such studied soil indicate the necessity of cyanobacterial inoculation to such soil samples. In this respect there is no response for development of lettuce plants in untreated soils (control). Furthermore, the lettuce seedlings were wilted, yellowish and finally dead. All applicable treatments (chemical, organic fertilizers and / or cyanobacterial treatments) showed high significant increases on shoot length and also in lettuce contents of chlorophyll contents, proteins and carbohydrates. However, the highest response in the above-mentioned features was recorded in the lettuce plants seeded in soil inoculated by Cyanobacteria especially that treated with $37.5 \%$ Anabaena and $37.5 \%$ Spirulina supplied with $12.5 \%$ urea and $12.5 \%$ compost (T11). These results could be related to the data obtained by Singh (1961) who reported the beneficial effects of cyanobacterial inoculation on the yield of sugarcane and grass and also that obtained by Kerni et. al., (1981) who found the cyanobacterial inoculation significantly promoted the growth of seedling of guava when compared with control. These results also in harmony with those adopted by De Cano, et. al., (1993) who reported that the length of rice leaves increased by $17 \%$ by cyanobacterial treatment compared with control. The positive effect of the Cyanobacteria on development of lettuce plants in the present investigation may attribute to the action of one or combination of many factors. Cyanobacteria are known to secrete several different categories of secondary metabolites, such as auxin-like substances (Venkataraman, 1981), cytokinin-like substances (Rodgres et. al., 1979), or gibberellin-like substances (Singh \& Trehan, 1973), vitamin B (Grieco \& Desrochers, 1978), or organic acids (Hellebust, 1974) and antibiotics (Moore, 1996; Schlegel et. al., 1999). Venkataraman (1981) reported that the excretion of ascorbic acid by Cyanobacteria is known and play a dual role as an exudates from Cyanobacteria in rice field, it can accelerate growth and development of the plant directly and as a constituent of the cyanobacterial cell, it may participate in processes of nitrogen fixation and nitrate reduction. In this respect, Haroun \& Hossein, (2003) confirmed that the cyanobacterial application either as inoculum or as extract increased the protein and chlorophyll for the tested plants and owed this to cyanobacterial inoculum and / or the suspension of the extract contain special set of biologically active compounds including plant growth regulators which may be decrease transpiration as well as to increase leaf chlorophyll and protein contents.

\section{Conclusion}

The results of this study confirm that it is not recommended to use urea or compost as unique fertilizers, but the addition of cyanobacterial SBI reducing the dissociation of urea towards formation of ammonia and nitrite, improve the available soil nutrients and also soil fertility which in turn affect the plant growth and productivity. Therefore, the inoculation of soil with $37.5 \%$ Anabaena oryzae 
$\left(22.5 \mathrm{~kg} \mathrm{ha}^{-1}\right)$ and $37.5 \%$ Spirulina meneghiniana $\left(22.5 \mathrm{~kg} \mathrm{ha}^{-1}\right)$ supplied with $12.5 \%$ urea $\left(7.5 \mathrm{~kg} \mathrm{ha}^{-1}\right)$ and $12.5 \%$ compost $\left(7.5 \mathrm{~kg} \mathrm{ha}^{-1}\right)$, can compensate some of the nutrients required for plant growth.

\section{References}

Abd-All, M. H.; Mahmoud, A. L. E. and Issa, A. A. (1994). Cyanobacterial biofertilizer improved growth of wheat. Phyton (Horn, Austria), 34 (1): 1118.

Allison, F. E. and Moris, M. J. (1930). Nitrogen fixation by blue-green algae. Sci., 71: 221-223.

Banerjee, M. and Kumar, H. (1992). Nitrogen fixation by Aulosira fertilissima in rice fields. Nautralia, Sao Paulo, 17: 51-58.

Barclay, W. R. and Lewin, R. A. (1985). Microalgal polysaccharides production for the conditioning of agricultural soils. Plant and Soil, 88: 159-169.

Bergman, B.; Gallon, J. R.; Rai, A.N. and Stal, L. J. (1997). $\mathrm{N}_{2}$-fixation by non-heterocystous cyanobacteria. FEMS Microbiol Rev., 19:139-185.

Blunden, G.; Jenkins, T. and Liu, Y. W. (1997). Enhanced leaf chlorophyll levels in plant treated with seaweed extract. J. of Appl. Phycol., 8: 535-543.

de Caire, G. Z.; de Cano, M. S.; de Mule, M. C.; Palma, R. M and Colombo, K. (1997). Exopolysaccharide of Nostoc muscorum (cyanobacteria) in the aggregation of soil particles. J. Appl. Phycol., 4: 249-253.

de Cano, M. S.; de Mule, M. C. Z.; de Caire, G. Z. and Halperin, D. R. (1993). Biofertilization of rice plants with cyanobacterium Tolypothrix tenus. (40 d.) Phyton 54 (2): 149-155.

de Mule, M., Caire, G., Cano, M., Palma, R. and Colombo, K. (1999). Effect of cyanobacterial inoculation and fertilizers on rice seedings and post harvest soil structure. Communications in Soil Science and Plant Analysis, 30 (1-2): 97-107.

Desikachary, T. V. (1959). Cyanophyta. Ph.D. Thesis, Botany Dept. Fac. of Scie. Madras Univ. India.

Dong, J.; Shang, S. and Su, B. (1995). Studies on the nitrogen fixation of algae in Beijing rice field: III. The use of he isotopic $\mathrm{N}^{15}$ trace assay estimated blue-green algae nitrogen fixing contribution. Acta Agri. Univ. Pek., 21(1): 7-11.

El-Ayouty, Y. M. (1998). Soil inoculation by blue-green algae and their effects on yield attributes of different rice varieties. Proceedings, Six ${ }^{\text {th }}$ Egyptian Botanical Conference, Cairo University. November 24-26. 11:221-230.

EL-Nawawy, A. S.; Lotfi, N. and Fahmy, M. (1958). Studies on the ability of some blue-green algae to fix nitrogen and their effect on growth and yield of rice plant. Agric. Res. Rev., 36: 308-320. 
El-Zeky, M. M.; El-Shahat, R. M.; Metwaly G. S. and Elham, M. A. (2005). Using Cyanobacteria or Azolla as alternative nitrogen sources for rice production. J. Agric. Mansoura Univ., 30 (9): 5567-5577.

Falshini, L.; Sparvoli, E. and Tomaselli, L. (1997). Effect of Nostoc (Cyanobacteria) inoculation on soil structure and stability of clay soils. Biology and Fertility of Soil, 23 (3): 346-352.

Fletcher, J. E. and Martin, W. P. (1948). Some effects of algae and mold in the rain crust of desert. soil. Ecol., 29: 95-100.

Ghazal, F. M. A. (1980). Studies on enzymatic activity in rice soil inoculated with blue-green algae. M. Sc. Thesis, Fac. of Agric., Al-Azhar Univ., Cairo, Egypt.

Ghosh, T. K. and Saha, K. C. (1993). Effect of inoculation with $\mathrm{N}_{2}$-fixing Cyanobacteria on the nitrogenase activity in soil and rhizosphere of wetland rice (Oryza sativa L.). Biot. Fertil. Soil, 16: 16-20.

Goldsborough, G. and Robinson, G. C. (1996). Pattern in wetlands. In: Stevenson RJ, Bothwell ML, Lowe RL (eds) Algal ecology. Freshwater benthic ecosystems. Academic, San Diego, 78-117.

Goyal, S. K. (1989). Stress compatibility in cyanobacteria. Phykos. 28: 267-273.

Grant, I. F., Roger, P. A. and Watanabe, I. 1986. Ecosystem manipulation for increasing biological $\mathrm{N}_{2}$-fixation by bluee-green algae (Cyanobacteria) in low land rice fields. Biological Agriculture and Horticulture, 3: 299-315.

Grieco, E. and Desrochers, R. (1978). Production de vitamine $B_{12}$ par une algae blue. Can. J. Microbiol., 24: 1562-1566.

Hardy. R. W. F., Burns, R. C. and Holsten, R. D. (1973). Application of acetylene-ethylene assay for measurement of nitrogen fixation. Soil Bio. Biochem., 5: 47-81.

Haroun, S. A. and Hossein, M. H. (2003). The promotive effect of algal biofertilizers on growth, protein pattern and some metabolic activities of Lupius termis plants grown in siliceous soil. Asian J Plant Science, 2 (13): 944-951.

Hassan, N. A. M. (2007). Studies on the algal flora distributed at Wadi-Sannur of the Eastern- desert of Egypt. M. Sc. Thesis, Faculty of Science, Beni-Suef University, Egypt.

Hellebust, J. A. (1974). Extracellular products. In algal physiology and biochemistry. Botanical Monographs Berkeley, CA. Ed.WDP Stewart. 10: 838-865.

Hesse, P. R. (1994). A textbook of soil chemical analysis, CBS Publishers \& Distributors. 485, Jain Bhawan, Bhola Nath Nagar, Shahdora, Delhi-110 032 (India).

Jackson, M. L. (1976). Soil chemical analysis. Constable. Co. Lt., London. 
Kaushik, B. D. and Murti, K. G. (1981). Effect of blue-green algae and gypsum application on physico-chemical properties of alkali soils. Phykos, 20 (1 and 2) 91-94.

Kerni, P. N., Shant, P. S. and Sapru, B. I. (1981). Effect of nitrogen fixing blue-green algae on Guava seedlings (Psidium gaujava. L.). Phykos, 20 (1 and 2): 95-98.

Ladha, J. K. and Reddy, P. M. (2003). Nitrogen fixation in rice systems: state of knowledge and future prospects. Plant Soil, 252: 151-167.

Lowe, L. E. (1993). Total and labile polysaccharide analysis. Canadian Society of Soil Science, Pp 342.

Lowery, O. H., Resebrought, N. J., Furr, . and Randall, R. J.(1951). Protein measurement with folin phenol regent. J. Biol. Chem., 193: 265-275.

Mandal, B.; Vlek P.G.L. and Mandal, L. N. (1999). Beneficial effects of bluegreen algae and Azolla, excluding supplying nitrogen, on wetland rice fields: a review. Biol Fertil Soils, 28: 329-342.

Markus, D. K.; Mckinnon, J. P. and Buccafuri, A. F. (1982). Aurmated analysis of nitric, nitrate and ammonium nitrogen in soils. New Jersy, Agric. Exp. Stn. Publication no. D. 15117-84.

McCormick, P.V. and O'Dell, M. B. (1996). Quantifying periphyton responses to phosphorus in the Florida Everglades: a synoptic-experimental approach. J. North Am Benthol Soc., 151: 450-468.

Metting, B. (1981). The systematic and ecology of soil algae. Botan. Rev., 47: 195-312.

Metting, B. and Rayburn, W. R. (1983). The influence of a microalgae conditioner on selected Washington soil. An empirical study. Soil Sci. Soc. Am. J., 47: 682-685.

Metting, B.; Rayburn, W. R. and Renaud, P. A. (1988). Algae and agriculture, In Algae and human affairs, Lembi C. A. and Waalaud, R. A. eds. Cambridge University Press, Cambridge,UK. 335-370.

Moore, R. E. (1996). Cyclic peptides and depsipeptides from Cyanobacteria: a review. J. Ind. Microbiol., 16: 134-143.

Nimah, M. N.; Ryan, J. and Chaudhry, M. A. (1983). Effect of synthetic conditioners on soil water retention, hydraulic conductivity, porosity and aggregation. Soil Sci. Soc. Am. J., 47: 742-745.

Oesterreicher, W. (1990). Ecological significant of algae in soil. Nachrichttenblatt des Deuschen Pflanzenschutzdienstes. 42(8): 122-126.

Olsen, S. R.; Colc, C. V.; Watanabe, F. S. and Dean, L. A. (1954). Estimation of available phosphorus in soil by sodium bicarbonate. U. S. Dept. Agric. Circ., 939.

Omar, H. H. (2000). Nitrogen-fixing abilities of some Cyanobacteria in sandy loam soil and exudates efficiency of rice grain germination. Egypt. J. Phycol., 1: 157-167. 
Paerl, H. W.; Pinckney, J. L. and Kucera, S. A. (1995). Clarification of the structural and functional roles of heterocysts and anoxic microzones in the control of pelagic nitrogen fixation. Limnol Oceanogr., 40:634-638.

Piper, C. S. (1950). Soil and plant analysis. A monogr. From the Water Agri. Inst. Univ. of Adelaide.

Potts, M. (1996). The anhydrobiotic cyanobacterial cell. Physiol Plant, 97:788794.

Potts, M. (1999). Mechanisms of desiccation tolerance in cyanobacteria. Eur. J. Phycol., 34:319-328.

Quesada, A.; Leganes, F. and Fernandezy-aleiente, E. (1997). Environmental factors controlling $\mathrm{N}_{2}$-fixation in Mediterranean rice fields. Microbiol. Ecology, 34:39-48.

Rodgers, G. A.; Bergman, B.; Henriksson, E. and Urdis, M. (1979). Utilisation of blue-green ass biofertilizers. Plant and Soil, 52: 99-107.

Rodrigo, V. and Eberto, N. (2007). Seasonal changes in periphyton nitrogen fixation in a protected tropical wetland. Biol Fertil Soils, 43: 367-372.

Roger, P. A. and Kulasooriya, S. A. 1980. Blue-green and rice. International Rice Research Institute, Los Banos, Philippines. 113.

Roger, P. A. and Watanabe, I. (1981). Algae and aquatic weeds as source of organic matter and plant nutrients for wetland rice. The International Rice Research Institute, Philippines, In organic matter and rice, 147-168.

Schlegel, I.; Doan, N. T.; de Chazal, N. and Smith, G. D. (1999). Antibiotic activity of new cyanobacterial isolates from Australia and Asia against green algae and Cyanobacteria. J. Appl. Phycol., 10: 471-479.

Scott, J. T.; Doyle, R. D. and Filstrup, C. T. (2005). Periphyton nutrient limitation and nitrogen fixation potential along a wetland nutrient-depletion gradient. Wetlands, 25:439-448.

Shields, L. M. and Durrell, L. M. (1964). Algae in relation to soil fertility. Bot. Rev., 30: 92-128.

Silke, R.; Vigdis, T.; Frida, L. D.; Lise, Ø. and Jörg, R. (2007). Nitrogen availability decreases prokaryotic diversity in sandy soils. Biol Fertil Soils, 43:449-459.

Singh, A. L.; Singh, P. K. and Pushp, L. (1988). Effect of different levels of chemical nitrogen (Urea) on Azolla and blue-green algae intercropping with rice. Fertilizer Research, 17: 47-59.

Singh, A. L.; Singh, P. K. and Singh, P. L. (1988). Comparative studies on the use of gree manuring, organic manuring and Azolla and blue-green algal biofertilizers to rice. J. Agric. Sci., 110 (2): 3337-343.

Singh, R. N. (1961). Role of blue-green algae in nitrogen economy of India. Indian Council Agric. Res., New Delhi, India.

Singh, V. P. and Trehan, T. (1973). Effects of extracellular products of Aulosira fertilissuna on the growth of rice seedlings. Plant and Soil, 38: 457-464.

Egyptian J. of Phycol. Vol. 8, $2007 \quad$ - 116 - 
Standard Method for Examination of Water and Wastewater (1998). $17^{\mathrm{TH}}$ AWWA-WPCF-APHA.

Tan, K. H. (1996). Soil sampling, preparation and analysis, Marcel Dekker, Inc., New York, USA.

Umbriet, W. W.; Burris, R. H.; Stauffer, J. F.; Cohen, P. P.; Johsen, W. J.; Lee Page, C. A.; Patter, V. R. and Schneider, W. C. (1969). Nanometric techniques, Manual describing methods applicable to the study of tissue metabolism. Burgess Publishing Co. USA. 239.

Venkataraman, G. S. (1981). Blue-green algae for rice production- a manual for its promotion. FAO Soils Bulletin, 64:24.

Vernon, L. P. and Seely, G. R. (1966). The chlorophylls. Acadimic Press. New York and London.

Zar, J. H. 1984. Biostatistical analysis. $2^{\text {nd }}$ Ed. Prentice. Hall, In., Englewood Cliffs, NJ.USA.

$$
\begin{aligned}
& \text { السيانوبكتيريا كمنظم إحيائي لتحسين صفات بعض أنواع التربة الغير ملائمة } \\
& \text { للزراعة } \\
& \text { قسم النبات - كلية العلوم - جامعة بني سويف إبراميم ـ مصر }
\end{aligned}
$$

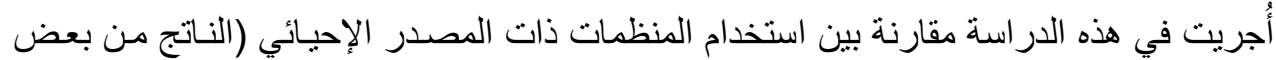

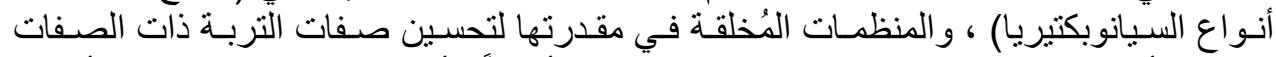

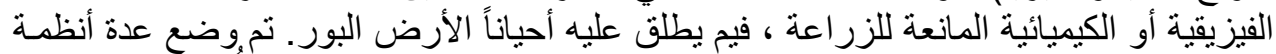

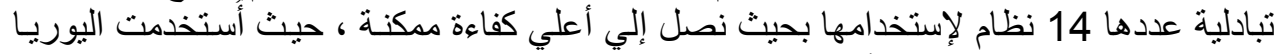

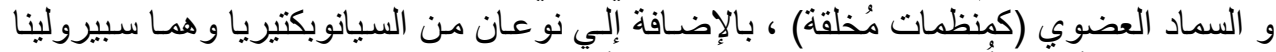

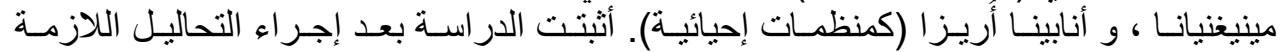

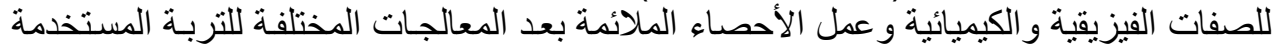

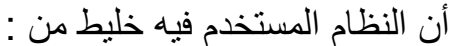

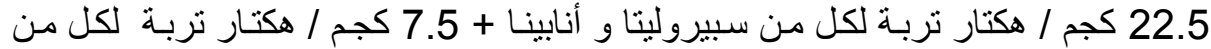

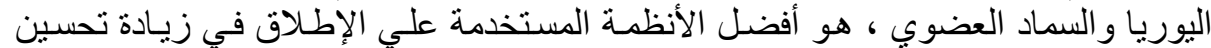
صفات التربة محل الدرأسة.

كما أثبتت الدراسة النطبيقية لهذ النظام من الأنظمة المستخدمة (مقارنة بغيره من الأنظمهة

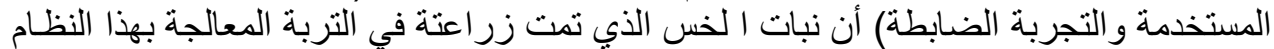

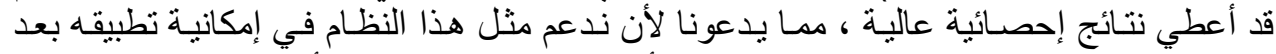

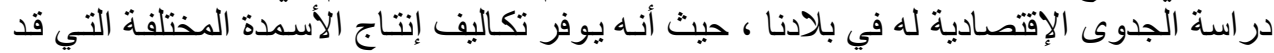

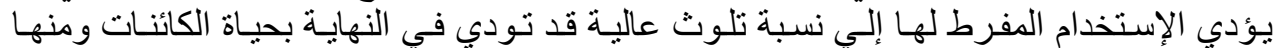
الإنسأن ، و هذا مايعطى قيمة تطبيقية للبحث. 